\title{
A new method for the simultaneous determination of cyanotoxins (Microcystins and Cylindrospermopsin) in mussels using SPE-UPLC-MS/MS
}

Leticia Díez-Quijada Jiménez ${ }^{\mathrm{a}} \quad$ (ldiezquijada@us.es), Remedios Guzmán-Guillén ${ }^{\mathrm{a}}$ *(rguzman1@us.es), Giorgiana M. Cătunescub (giorgiana.catunescu@usamvcluj.ro), Alexandre Campos $^{\mathrm{c}}$ (acampos@ciimar.up.pt), Vitor Vasconcelos ${ }^{\mathrm{c}, \mathrm{d}}$ (vmvascon@fc.up.pt), Ángeles Jos ${ }^{\mathrm{a}}$ (angelesjos@us.es), Ana M. Cameán ${ }^{a}$ (camean@us.es).

${ }^{a}$ Area of Toxicology, Faculty of Pharmacy, University of Sevilla, Sevilla, Spain.

${ }^{b}$ University of Agricultural Sciences and Veterinary Medicine Cluj-Napoca, Calea Mănăștur 3-5, 400372, ClujNapoca, Romania

${ }^{c}$ Interdisciplinary Centre of Marine and Environmental Research, University of Porto, Matosinhos, Portugal ${ }^{d}$ Department of Biology, Faculty of Science, University of Porto, Portugal

*Corresponding author: Remedios Guzmán-Guillén Area of Toxicology, Faculty of Pharmacy, University of Sevilla.C/ Profesor García González, no 2. C.P. 41012, Seville. Spain.

E-mail address: rguzman1@us.es 


\begin{abstract}
The aim of this study was to optimize the extraction conditions of Microcystin-LR (MC-LR), Microcystin-RR (MC-RR), Microcystin-YR (MC-YR) and Cylindrospermopsin (CYN) simultaneously from mussels by using response surface methodology (RSM) and to validate the method by a dual solid phase extraction (SPE) system combined with ultra-performance liquid chromatography-tandem mass spectrometry (UPLC-MS/MS). The optimal parameters were: $90 \% \mathrm{MeOH}(\% \mathrm{v} / \mathrm{v})$ for the extraction, a solvent/sample ratio of 75 and $15 \% \mathrm{MeOH}$ in the extract before loading onto SPE. Mussels were spiked at 10; 37.5 and $75 \mathrm{ng} \mathrm{g}^{-1}$ fresh weight (f.w) of the 4 toxins, showing linear ranges of $0.5-75 \mathrm{ng} \mathrm{g}^{-1} \mathrm{f.w}$; low values for the limits of detection (0.01-0.39 $\mathrm{ng} \mathrm{g}^{-1}$ f.w.) and quantification (0.23-0.40 $\mathrm{ng} \mathrm{g}^{-1}$ f.w.); acceptable recoveries (70.37-114.03\%) and relative standard deviation (\%RSDIP) values (2.61-13.73\%). The method was successfully applied to edible mussels exposed to cyanobacterial extracts under laboratory conditions, and it could allow the monitoring of these cyanotoxins in environmental mussel samples.
\end{abstract}

Keywords: Cyanotoxins, Response surface methodology, Box-Behnken Design, method validation, solid phase extraction, mussels 


\section{Funding sources}

-Spanish Ministry of Economy and Competitiveness (AGL2015-64558-R, MINECO/FEDER, UE) and the grant FPI (BES-2016-078773).

-EFSA funding under the EU-FORA Programme

-Projects MOREBIVALVES (PTDC/ASP-PES/31762/2017) and UID/Multi/04423/2013 co-

financed by NORTE 2020, Portugal 2020 and the European Union through the ERDF, and by Portuguese Science Foundation (Fundação para a Ciência e a Tecnologia, FCT) 


\section{Introduction}

Nowadays, there is an increase in the cyanobacteria blooms over the world as a consequence of anthropogenic activities and climate change (Sanseverino et al., 2017). These cyanobacteria have the ability to produce toxic secondary metabolites called cyanotoxins (Funari et al., 2017). Among the variables involved in the prediction of the cyanotoxins presence, water temperature, turbidity, total phosphorus and alkalinity have an important role (García Nieto et al., 2013). Cyanotoxins are different in their chemical structures and toxicities, and they are classified as hepatotoxins, cytotoxins, dermatotoxins, neurotoxins, and irritant toxins, according to their mechanism of action (Testai et al., 2016). Microcystins (MCs) and cylindrospermopsin $(\mathrm{CYN})$ are usually the most investigated cyanotoxins because of their wide distribution and toxicity.

MCs can be produced by different genera such as Microcystis, Planktothrix and Dolichospermum (Buratti et al., 2017). MCs are cyclic heptapeptides with the general structure cyclo(D-Ala ${ }^{1} \mathrm{X}^{2}$-D-MeAsp ${ }^{3}-Z^{4}-$ Adda $^{5}$-D-Glu $\left.{ }^{6}-\mathrm{Mdha}^{7}\right)$, where Adda is (2S,3S,8S,9S)-3amino-9-methoxy-2,6,8-trimethyl-10-phenyldeca-4,6-dienoic acid, D-MeAsp ${ }^{3}$ is D-erythro-3methyl aspartic acid, Mdha is $\mathrm{N}$-methyldehydroalanine; and $\mathrm{X}, \mathrm{Z}$ are variable L-amino acids (Sivonen and Jones, 1999). So far, at least $246 \mathrm{MCs}$ congeners have been recognized to date (Spoof and Catherine, 2017), with MC-LR being the most toxic (Díez-Quijada et al., 2019a). Among MCs, MC-LR, MC-RR and MC-YR are the most common variants, as a result of the presence of leucine (L), arginine (R) and tyrosine (Y), respectively, in the positions $2(\mathrm{X})$ and 4 (Z) (Harada et al., 1990; Hooser et al., 1991; Sivonen and Jones, 1999). The mechanism of action of MCs is related to the inhibition of protein serine/threonine phosphatases through their binding mainly to PP1 and PP2A (Buratti et al., 2017; Bagu et al., 1997). 
Many cyanobacterial genera have been identified as CYN producers such as Cylindrospermopsis, Aphanizomenon, Umezakia, Chrysosporum and Anabaena, however, the main producers are C. raciborskii and Aph. ovalisporum (Buratti et al., 2017; Kokocinski et al., 2017). CYN is a stable tricyclic alkaloid with a guanidine moiety connected to a hydroxymethyluracil through a hydroxyl bridge (Ohtani et al., 1992). CYN is highly water soluble because of its zwitterionic properties (Chiswell et al., 1999). It is well known that CYN produces an inhibition of protein (Terao et al., 1994) and glutathione (Runnegar et al., 1995) synthesis, and it needs to be activated metabolically by cytochrome P450, suggesting its progenotoxic activity (Norris et al., 2002; Štraser et al., 2011; Díez-Quijada et al., 2019b).

Often an $80 \%$ of human exposure to cyanotoxins is thought to result from ingestion of contaminated drinking water (Ibelings and Chorus, 2007; Greer et al., 2018), followed by consumption of contaminated vegetables (Machado et al., 2017; Cao et al., 2019; Llana-RuízCabello et al., 2019) and edible aquatic food (Gutiérrez-Praena et al., 2013). Several studies reported MCs accumulation in mussels (Vasconcelos et al., 1995; Vareli et al., 2012; Baralla et al., 2017; Kim et al., 2017), but data on CYN are scarcer (Anderson et al., 2003; Saker et al., 2004). This accumulation represents a potential hazard for human health (Gutiérrez-Praena et al., 2013; Testai et al., 2016; Díez-Quijada et al., 2019a, 2019c). Provisional Tolerable Daily Intakes (TDI) of 0.04 and $0.03 \mu \mathrm{g} / \mathrm{kg}$ of body weight (b.w.)/day were established for MCs and CYN, respectively (Chorus and Bartram, 1999; Humpage and Falconer, 2003). Estuaries and coast environments can be affected by contaminated freshwaters (Tatters et al., 2017). These situations are very particular but frequent in certain regions, and are documented in the freshwater and saltwater invertebrates (Miller et al., 2010; Gibble et al., 2016; Peacock et al., 2018). Bivalves are particularly useful for assessing accumulation of cyanotoxins due to their widespread, being 
prey of marine mammals and consumed by humans; they are important vectors of these toxins in the marine trophic chain. Therefore, it is important to establish methods for the determination and quantification of these toxins in these organisms to monitor the state of these ecosystems and the degree of contamination.

Mass spectrometry (MS) combined with liquid chromatography (LC-MS, LC-MS/MS) is used to determine MCs and CYN in various matrices, such as water, biomass of natural blooms, cyanobacterial strains, mollusks and fish (Cameán et al., 2004; Moreno et al., 2005; Ruiz et al., 2005; Guzmán-Guillén et al., 2012a, 2012b, 2015; Zervou et al., 2017). In particular, ultraperformance liquid chromatography tandem mass spectrometry (UPLC-MS/MS) is a quicker and more selective analytical method that is employed to determine cyanotoxins in water (Oehrle et al., 2010; Greer et al., 2016; Pekar et al., 2016), fish (Guzmán-Guillén et al., 2017; Prieto et al., 2017; Manubolu et al., 2018) and mussels (Turner et al., 2018).

The European Food Safety Authority (EFSA) has set as a priority the development of analytical validated methods to determine cyanotoxins in complex matrices (Testai et al., 2016), and in this sense, methods for multitoxin determination are of particular interest. Studies aiming at a simultaneous determination of cyanotoxins in mussels are limited and only detect MCs, but not CYN (Gkelis et al., 2006; Mekebri et al., 2009; Papadimitriou et al., 2012; Preece et al., 2015a, 2015b; Baralla et al., 2017; Kim et al., 2017; Turner et al., 2018). Moreover, only two of them have been validated (Mekebri et al., 2009; Turner et al., 2018), and although Turner et al. (2018) tried to detect CYN on their analyses, it was not possible. Recently, a method for the simultaneous determination of MCs and CYN in vegetables was developed (Díez-Quijada et al., 2018). 
Response surface methodology (RSM) is a useful approach of process optimization considering the experimental design. It is an effective mathematical and statistical tool designed to model, analyze and optimize complex processes. It is usually used when a response of interest (called a dependent variable), such as compound extraction yields in this study, is influenced simultaneously by several factors (independent variables) (Addinsoft, 2019). It has different variations, however the Box-Behnken Design (BBD) is of current interest because it contains a smaller number of experiments with reliable results (Pal and Jadeja, 2019; Rodsamran and Sothornvit, 2019). In the BBD the points of experiments are generated on a sphere around the center point, the number of different factor levels is minimized, and the center point is repeated in order to maximize the prediction precision around the supposed optimum similar to the Central Composite Design (CCD) (Addinsoft, 2019). Its efficiency has been showed to be greater than that of Central Composite Design and much greater than that of Three-Level Full Factorial (Ferreira et al., 2007; Pal and Jadeja, 2019). In addition, the BBD generates less extreme experimental combinations compared to $\mathrm{CCD}$, which uses variables that have simultaneous extreme value (at the corners of the hypercube) (Otto, 2016). Thus, BBD can provide a model with a better fit. Many studies dealing with the optimization of extraction procedures used the BBD (Anuar et al., 2013; Y1lmaz et al., 2015; Oliveira et al., 2016; Lim et al., 2019).

The main objective of this study was for the first time the optimization of a sensitive method for the simultaneous extraction and determination of four cyanotoxins (MC-LR, MC-RR, MC-YR and CYN) from mussels, using a dual solid phase extraction (SPE) cartridge system combined with UPLC-MS/MS for their determination and RSM for optimization procedures. 


\section{Materials and methods}

\subsection{Chemicals and Reagents}

Commercial standards for MC-LR, MC-RR and MC-YR (99\% purity) and CYN (95\% purity) were supplied by Enzo Life Sciences (Lausen, Switzerland). Deionized water (18.2 M $\Omega$ $\mathrm{cm}$ resistivity) was obtained from an ultrapure water purification system (NANOpure Diamond $^{\mathrm{TM}}$, Barnstead, USA). HPLC-grade methanol (MeOH), dichloromethane (DCM), hexane, formic acid (FA) and sodium hydroxide $(\mathrm{NaOH})$ were supplied by Merck (Darmstadt, Germany). Cartridges for the SPE were C18 Bakerbond ${ }^{\circledR}(500 \mathrm{mg}, 6 \mathrm{~mL}$, Dicsa, Andalucía, España), and graphitized carbon cartridges BOND ELUT® $(500 \mathrm{mg}, 6 \mathrm{~mL}$, Agilent Technologies, Amstelveen, The Netherlands, Europe). Nanosep® Centrifugal Devices with BioInert ${ }^{\circledR}$ Membrane (modified nylon) $0.45 \mu \mathrm{m}$ and $25 \mathrm{~mm}$ Syringe Filters with $0.2 \mu \mathrm{m}$ cellulose acetate membrane were supplied by PALL Corporation (New York, USA) and VWR (International Radnor, Pennsylvania, USA), respectively. LC-MS grade reagents were employed for UHPLC-MS/MS analyses: water and acetonitrile, purchased from VWR International (Fontenay-sous-Bois, France), and FA from Fluka (Steinheim, Germany). Standard multitoxin solutions containing the four cyanotoxins (MC-LR, MC-RR, MC-YR and CYN) were prepared when needed in $20 \% \mathrm{MeOH}$ and diluted to three different concentrations (20, 75 and $150 \mathrm{ng} \mathrm{mL}^{-}$

${ }^{1}$ ) to obtain $10,37.5$ and $75 \mathrm{ng} \mathrm{g}^{-1}$ f.w., respectively, by spiking $1 \mathrm{~g}$ of mussels f.w. with $500 \mu \mathrm{L}$ of the standard solutions. Mussels were obtained from a local supermarket, ready for human consumption. 


\subsection{Optimization of the extraction method}

\subsubsection{Preliminary extraction tests}

Preliminary tests were performed on mussels spiked with $250 \mathrm{ng} \mathrm{g}^{-1} \mathrm{f}$.w. by applying the method of Díez-Quijada et al. (2018) for multitoxin analysis in vegetables with some modifications: the extraction procedure was repeated twice; extraction with or without hexane (10 $\mathrm{mL})$ to eliminate the lipids; $\mathrm{MeOH}$ concentration was reduced to $25 \%$ before passing the sample through the cartridges in the SPE (Mekrebi et al., 2009; El Ghazali et al., 2010; Greer et al., 2016); and the extracts were cleaned by 2 options: using SPE with the dual cartridge system (C18 and porous graphitic carbon-PGC-) or by filtering (nanosep devices $-0.45 \mu \mathrm{m}$ - and syringe filters - $0.2 \mu \mathrm{m}-$ ) (Turner et al., 2018). The use of hexane in general yielded the poorest results (5-8\%), while applying only SPE instead of filtering always resulted in higher recovery yields; indeed, the best recoveries were obtained when using SPE without hexane (46-66\%) (data not shown). Taking this into account, we decided to continue with the optimization of the extraction method without hexane, using SPE, and reducing the percentage of $\mathrm{MeOH}$ to at least $25 \%$ before SPE.

\subsubsection{Response surface methodology - Box-Behnken Design}

A BBD experimental design of 15 experimental runs was used to analyze the optimal extraction conditions for MC-LR (Y1), MC-RR (Y2), MC-YR (Y3) and CYN (Y4) from mussels spiked with a solution mixture. Three independent variables were considered at 3 levels: $\mathrm{MeOH}$ concentration (\% v/v) (X1) of the solvent used for extraction $(80 \%, 90 \%, 100 \%)$, solvent/sample ratio $(\mathrm{X} 2)(25,50,75)$ and $\mathrm{MeOH}$ concentration of the extract for loading onto SPE (\% v/v) (X3) $(5 \%, 15 \%, 25 \%)$. These 3 factors were chosen because they were the ones with higher heterogeneity among the scientific literature regarding cyanotoxins extraction. In the case of the 
first parameter ( $\mathrm{MeOH}$ percentages for extraction), it was chosen based on the objective of the method, which aims to optimize the best conditions for extraction of the four cyanotoxins (CYN, MC-LR, MC-RR and MC-YR), so a solvent that was suitable for extraction of all cyanotoxins, such as $\mathrm{MeOH}$, was chosen in order not to compromise the yields of any of them. The $\mathrm{MeOH}$ percentages chosen were selected according to the data reported by other authors for cyanotoxins extraction from waters, mollusks, crustaceans or fish: $50 \% \mathrm{MeOH}$ (Freitas et al., 2014), 75\% MeOH (García et al., 2010; Greer et al., 2016), 75:20:5 MeOH:H $2 \mathrm{O}: \mathrm{BuOH}$ (Manubolu et al., 2018), or $80 \% \mathrm{MeOH}$ (Turner et al., 2018). Moreover, previous extraction of these cyanotoxins yielded higher recoveries using a minimum of $80 \% \mathrm{MeOH}$ (Díez-Quijada et al., 2018). With respect to solvent/sample ratios, the factors were selected taking into account the ratios chosen by others authors in the scientific literature: 4 for MCs extraction from crabs (García et al., 2010); 5 for CYN extraction from mussels (Freitas et al., 2016); 10 for MCs extraction from fish muscle (Guzmán-Guillén et al., 2011), and 40 and 250 for extraction of CYN from fish muscle and liver, respectively (Guzmán-Guillén et al., 2015). Moreover, Lim et al. (2019) determined an optimal solvent/sample ratio of 30 for extraction of antibacterial activity from plants using RSM with BBD. Finally, previous works diluted the extract with water before the clean-up procedure, not to exceed 5\% MeOH (Mekrebi et al., 2009), 15\% MeOH (Greer et al., 2016), or 20\% $\mathrm{MeOH}$ (El Ghazali et al., 2010). Therefore, in our work, the MeOH percentage before SPE was reduced to 5,15 or $25 \%$.

The following yields (responses, Yi) of the 4 cyanotoxins were considered as target parameters for the multi-response analysis (Addinsoft, 2019; Lim et al., 2019): lower value L = $80 \%$; left target $\mathrm{TL}=95 \%$; right target value $\mathrm{TR}=100 \%$ and upper value $\mathrm{U}=110 \%$, as suggested by current literature (González and Herrador, 2007; González et al., 2010). Three replicates at 
the center of the design were set for the estimation of the pure error sum of squares (Ferreira et al., 2007; Lim et al., 2019). The experimental runs were randomized and carried out in unblocked design.

\subsection{Extraction of cyanotoxins and SPE}

First, the UPLC-MS/MS method was tested for the analysis of MC-LR, MC-RR, MCYR and CYN, acquiring mass spectra and adjusting the mobile phase strength. Ten calibration standards $\left(0.5-75 \mu \mathrm{g} \mathrm{L}^{-1}\right)$ were prepared with the 4 cyanotoxins to obtain their calibration curves in $20 \% \mathrm{MeOH}$ as solvent. Then, matrix-matched calibration curves $\left(0.5-75 \mu \mathrm{g} \mathrm{L} \mathrm{L}^{-1}\right)$ were prepared from the mussels extracts, to reach linear ranges of $0.5-75 \mu \mathrm{g} \mathrm{L}^{-1}$, equivalent to $0.5-75$ ng g ${ }^{-1}$ f.w. (0.5; $1 ; 2.5 ; 5 ; 10 ; 15 ; 25 ; 35 ; 50 ;$ and 75 ng g $^{-1}$ f.w.).

Control fresh live mussels were obtained from a local supermarket; they were shucked to remove and separate the shells, and the flesh was homogenized. Then, $1 \mathrm{~g} \mathrm{f.w}$. portions (1.02 \pm $0.07 \mathrm{~g}$ f.w.) were spiked with $500 \mu \mathrm{L}$ of a multitoxin solution containing a mixture of the cyanotoxins, at three concentration levels: 20 ; 75 ; and $150 \mu \mathrm{g} \mathrm{L}^{-1}$, leading to $10 ; 37.5$; and $75 \mathrm{ng}$ $\mathrm{g}^{-1}$ f.w. Mussels were left with the toxin solution for $20 \mathrm{~min}$ (Prieto et al., 2017) and immediately frozen $\left(-20^{\circ} \mathrm{C}\right)$ and lyophilized. Weight loss before lyophilization was about $85 \%$, leading to a mean weight of $0.15 \pm 0.01 \mathrm{~g}$ dry weight (d.w.).

Three concentrations of $\mathrm{MeOH}$ with the different solvent/sample ratios cited in section 2.3.1 were assayed for toxin extraction from the mussels. Then, samples were sonicated and stirred (15 min each step), centrifuged (3,700 rpm, $15 \mathrm{~min}$, room temperature) and the supernatants were collected. This process was repeated twice; and then, both supernatants were joined, concentrated in a rotary evaporator and diluted to the different $\mathrm{MeOH}$ concentrations tested for loading onto SPE. 
The SPE was a dual cartridge system C18 on top and PGC on bottom (Zervou et al., 2017). Zervou et al. (2017) showed that the use of a dual sequential HLB-PGC for SPE assembly would enhance the overall extraction efficiency of the majority of cyanotoxins from water compared to using a single SPE. The method enabled their simultaneous extraction and preconcentration, despite variations in their physicochemical properties. Reverse phase C18 cartridges are suitable for MCs extraction, as moderately polar organic compounds, and the use

of PGC is preferred for CYN extraction, due to its high water solubility. Cartridges were activated with DCM, $100 \% \mathrm{MeOH}$ and $\mathrm{H}_{2} \mathrm{O}$ at $\mathrm{pH} 11$ (6 mL each). The extracts, adjusted at a $\mathrm{pH}$ 11, were passed through and the cartridges were let dry for $5 \mathrm{~min}$. Then, the order of cartridges was reversed (PGC on top and C18 on bottom) because CYN is not retained in the C18 cartridge. Analytes were eluted with $10 \mathrm{~mL}$ of $\mathrm{DCM} / \mathrm{MeOH}(40 / 60)+0.5 \% \mathrm{FA}$. The addition of DCM and FA is compulsory for the simultaneously extraction MCs and CYN because of their different polarities. In agreement, Zervou et al. (2017) showed that $\mathrm{MeOH}$ with $0.5 \% \mathrm{FA}$ provided optimum recoveries for the majority of the cyanotoxins. Finally, the extracts were evaporated to dryness in a rotary evaporator and resuspended in $1 \mathrm{~mL} 20 \% \mathrm{MeOH}$.

\subsection{Chromatographic Conditions}

Chromatographic separation was performed in a UPLC Acquity (Waters) coupled to a Xevo TQ-S micro (Waters) consisting of a triple quadrupole mass spectrometer equipped with an electrospray ion source, operating in positive mode. UPLC analyses were performed on a $100 \mathrm{x}$ 2.1 mm XSelect HSS T3 $2.5 \mu \mathrm{m}$ column, at a flow rate of $0.45 \mathrm{~mL} \mathrm{~min}^{-1}$. A binary gradient consisting of (A) water and (B) acetonitrile, both containing $0.1 \%$ formic acid (v/v) was employed, and injection volume was $5 \mu \mathrm{L}$. The elution profile was: $2 \% \mathrm{~B}$ (0.8 min), linear gradient to $70 \% \mathrm{~B}(6.2 \mathrm{~min}), 100 \% \mathrm{~B}(1 \mathrm{~min})$ and finally $2 \% \mathrm{~B}(2 \mathrm{~min})$. Multiple Reaction 
Monitoring (MRM) was applied, where the parent ions and fragments ions were monitored at Q1 and Q3, respectively. The mass spectrometer was set to the following optimised tune parameters for UPLC-ESI-MS/MS analyses: capillary voltage to $1.0 \mathrm{kV}$; source temperature to $500{ }^{\circ} \mathrm{C}$; source desolvation gas flow to $1000 \mathrm{~L} / \mathrm{h}$; and source cone gas flow to $50 \mathrm{~L} \mathrm{~h}^{-1}$.

The transitions employed for setting up the UPLC-MS/MS system were: 996.5/135.0, 996.5/213.1, and 996.5/996.5 for MC-LR; 520.2/135.0 and 1039.5/135.0 for MC-RR; 1046.5/135.0, 1046.5/213.0, and 1046.5/1046.5 for MC-YR; 416.2/194.0 and 416.2/176.0 for CYN. The first values for each toxin were used for quantification, while the others for confirmation (Díez-Quijada et al., 2018).

\subsection{Analytical Criteria for Method Validation}

The Magnusson and Örnemark, (2014), AOAC (2016), and González and Herrador, (2007) guidelines were followed to establish selectivity, limits of detection and quantification, working range, trueness, and precision for the validation of the extraction and quantification method. Thus, $0.5 \mathrm{~mL}$ of cyanotoxins at 20; 75; and $150 \mu \mathrm{g} \mathrm{L}^{-1}$ were spiked into $1 \mathrm{~g}$ of fresh mussels to obtain $10 ; 37.5$; and $75 \mathrm{ng} \mathrm{g}^{-1} \mathrm{f} . \mathrm{w}$. of each cyanotoxin. These concentrations were selected taking into account those reported in the scientific literature (Saker et al., 2004; Vareli et al., 2012; Freitas et al., 2016; Kim et al., 2017; Turner et al., 2018).

The limits of detection (LOD) and quantification (LOQ) were obtained based on the standard deviation of the response and the slope of the calibration curve, as 3xSD/slope (LOD) and 10xSD/slope (LOQ). The standard deviation (SD) was calculated based on the calibration curve using the residual standard deviation of the regression line (Miller and Miller, 2000; ICH, 2005). 
The extractions were performed as described in section 2.3 in triplicate each day and on 3 different days, covering the working range. The optimal values for the independent variables X1, $\mathrm{X} 2$ and X3 (as detailed in section 3.2) were used: $90 \% \mathrm{MeOH}$ for extraction, solvent/sample ratio of 75 (means adding $11.25 \mathrm{~mL}$ of solvent each time) and $15 \% \mathrm{MeOH}$ in the extract for loading onto SPE. Finally, the results were compared with the respective tabulated reference values for each concentration level.

\subsection{Application of the validated method to laboratorial-exposed mussel samples}

Mussels (60 mm $\pm 15 \mathrm{~mm}$ ) were harvested at Praia da Memória (Amorim and Vasconcelos, 1999; Puerto et al., 2011), located in the North Coast of Portugal and they were transported in thermal boxes with sea water to the laboratory. Algae and/or invertebrates attached to their shells were removed. They were fed daily with the green microalga Parachlorella kessleri $\left(1 \times 10^{5}\right.$ cell/mL) (Amorim and Vasconcelos, 1999). The water from the aquaria was renewed every 2 days. During the exposure phase, mussels were fed twice a day toxic cultures of $M$. aeruginosa and C. ovalisporum for 14 days, at concentrations of $2.3 \times 10^{-3} \mu \mathrm{g}$ MC-LR/mL and $7.85 \times 10^{-1} \mu \mathrm{g}$ CYN/mL. After the intoxication phase, the toxic cultures were replaced by the non-toxic P. kesseleri $\left(1 \times 10^{5}\right.$ cells $\left./ \mathrm{mL}\right)$ to feed the mussels twice a day for 14 additional days (depuration phase). Four specimens were analyzed for each phase (exposure and depuration).

\subsection{Statistical analyses and model fitting}

A BBD experimental design was used to obtain the variable combinations for the experimental runs. The linear, interaction, and squared coefficients of the RSM were determined by least square regression. Analysis of variance (ANOVA) and Mann-Whitney two-tailed test were performed to analyze the fitting of the model. A comparison between the computed optimum conditions and experimental runs was tested using an independent sample t-test. 
Precision and recovery for the validation of the extraction and quantification method were obtained by applying a one-factor analysis of variance (ANOVA). Statistical significance was considered at $\mathrm{P}<0.05$. The $2 \mathrm{D}$ response surface charts and the desirability functions were also computed. All the statistical analyses and model fitting were performed using XLSTAT software (Addinsoft, New York, USA, Version 2018.7.55098) (Addinsoft, 2019).

\section{Results and Discussion}

\subsection{Calibration Study}

\subsubsection{Linearity}

The response as a function of concentration was calculated from standards of MC-LR, MC-RR, MC-YR, and CYN prepared in mussel extracts, obtaining four 10-point calibration curves with a linear range within $0.5-75 \mathrm{ng}$ toxins $\mathrm{g}^{-1}$ f.w. mussels. The regression equations obtained were $\mathrm{y}=$ 317.021x-29.729 for MC-LR $\left(\mathrm{R}^{2}=0.9964\right), \mathrm{y}=470.960 \mathrm{x}+98.574$ for $M C-R R\left(\mathrm{R}^{2}=0.9972\right), \mathrm{y}=$ 217.35x-25.334 for MC-YR $\left(\mathrm{R}^{2}=0.9947\right)$ and $\mathrm{y}=260.680 \mathrm{x}+2.193$ for $\mathrm{CYN}\left(\mathrm{R}^{2}=0.9973\right) . \mathrm{R}^{2}$ values have been improved in the present work for MC-RR compared with those obtained by Turner et al. (2018); besides, in the present study, CYN has been also determined.

The corresponding Huber plots were obtained with the four 10-point calibration curves performed in mussel extracts (Figure 1). The calibration plot represents the relationship between the signal response/analyte concentrations versus analyte concentration (Huber, 1998). The target line in Figure 1 represents the median signal/concentration calculated for all the concentrations assayed, and then two action lines are drawn at 105 and 95\% this median value. All the actual values obtained for each tested concentration were within the median value $\pm 5 \%$ for MC-LR, MC-YR and CYN. Thus, the proposed method demonstrates to be linear within 0.5-75 $\mathrm{ng} \mathrm{g}^{-1}$ f.w. for MC-LR, MC-YR, and CYN; and within 1-75 $\mathrm{ng} \mathrm{g}^{-1}$ f.w for MC-RR. 

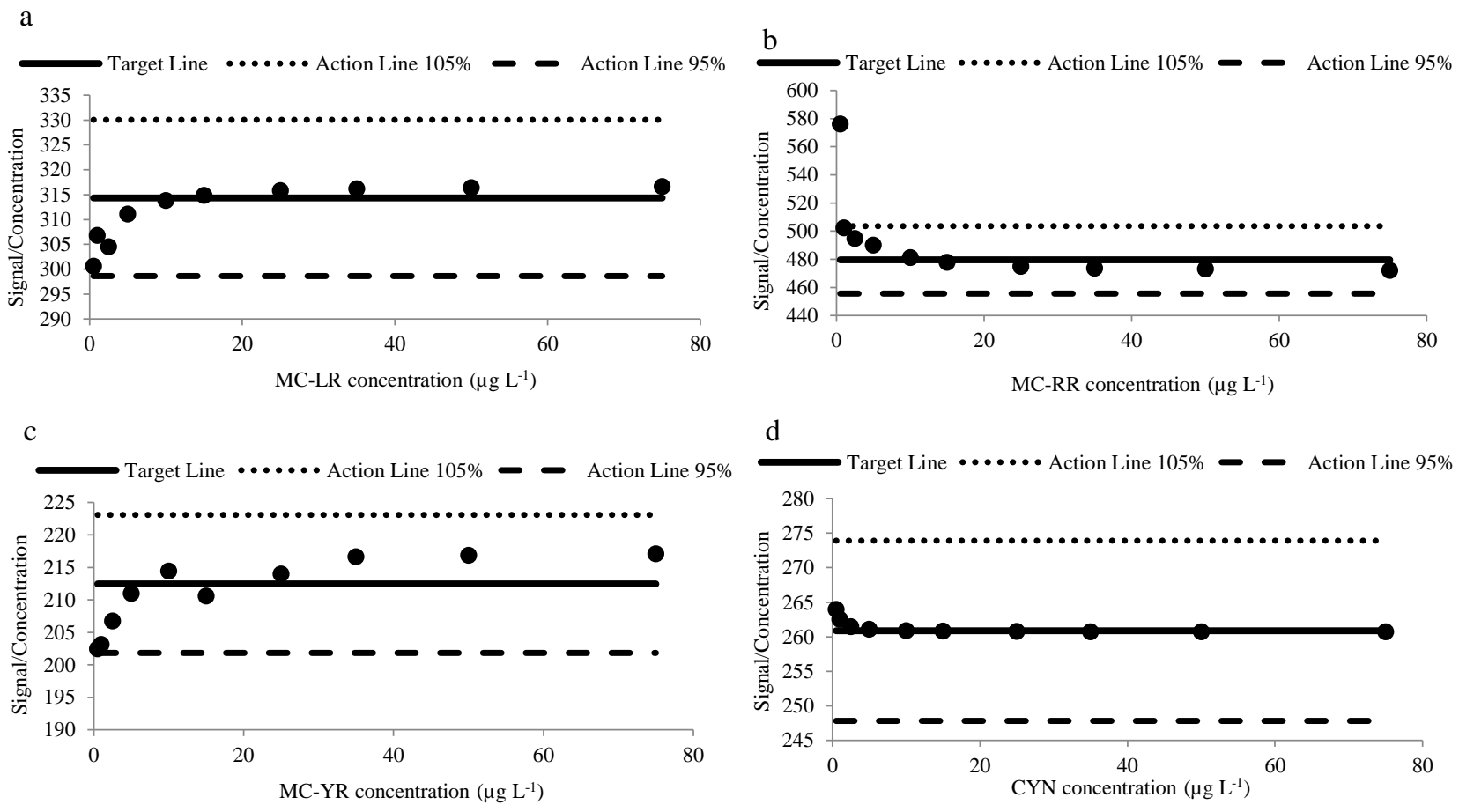

Figure 1. Response linearity in mussel (Huber plot) for (a) MC-LR; (b) MC-RR; (c) MC-YR and (d) CYN.

\subsubsection{Sensitivity}

LOD and LOQ are presented in Table 1, and both values were lower than the reported guideline values (GV) for waters of $1 \mu \mathrm{g} \mathrm{L}^{-1}$ proposed for MCs (WHO, 2003) and for CYN (Humpage and Falconer, 2003). Although these are different matrices, the values are compared to those GV in waters because this is the media where cyanotoxins reach the mussels. The lowest LOD was obtained for MC-RR, followed by MC-YR, MC-LR and finally CYN. The results obtained are lower than the LOD and LOQ values reported by other authors in mussels (Baralla et al., 2017; Turner et al., 2018), fish (Manubolu et al., 2018), fish and crayfish (Ríos et al., 2013), other aquatic organisms (Gkelis et al., 2006), and vegetables (Li et al., 2014; DíezQuijada et al., 2018). Moreover, their study presents two limitations; one concerning quantification below these reported values, and the second related to the applicability of the 
method for the extraction of other MC variants. Turner et al. (2018) reported higher or similar LOD and LOQ for some MCs congeners in mussels, but they do not include CYN on this analysis. Our study allows for the first time the analysis of MC congeners and CYN simultaneously, showing adequate and lower LOD and LOQ values for all of them compared to the existing values reported by other methods in mussels. 
Table 1. Estimations of recoveries (experimental, predicted and error $(\%)$ ); within-day repeatability $\left(\mathrm{S}_{\mathrm{w}}\right)$; between-day repeatability $\left(\mathrm{S}_{\mathrm{B}}\right)$; intermediate precision $\left(\mathrm{S}_{\mathrm{IP}}\right)$; and its relative standard deviation (\%RSDIP) for MC-LR, MC-RR, MC-YR and CYN. Limits of detection (LOD) and quantification (LOQ) for the mussel matrix.

\begin{tabular}{|c|c|c|c|c|c|c|c|c|c|c|}
\hline & \multicolumn{10}{|c|}{ Validation parameters } \\
\hline & $\begin{array}{c}\text { Toxin } \\
\text { concentration } \\
\text { level }\left(\mathrm{ng} \mathrm{g}^{-1}\right. \\
\left.\text { f.w. }{ }^{\mathrm{a}}\right) \\
\end{array}$ & $\begin{array}{c}\text { Experimental } \\
\text { Recovery } \\
(\%)\end{array}$ & $\begin{array}{c}\text { Predicted } \\
\text { Recovery } \\
(\%)\end{array}$ & $\begin{array}{c}\% \text { Error } \\
\text { of } \\
\text { prediction }\end{array}$ & $\mathbf{S}_{\mathbf{W}}$ & $\mathbf{S}_{\mathbf{B}}$ & $\mathbf{S}_{\text {IP }}$ & $\begin{array}{c}\text { RSD }_{\text {IP }} \\
(\%)\end{array}$ & $\begin{array}{l}\operatorname{LOD}(n g \\
\left.g^{-1} \text { f.w. }{ }^{a}\right)\end{array}$ & $\begin{array}{l}\text { LOQ (ng } \\
\left.\text { g }^{-1} \text { f.w. } .^{a}\right)\end{array}$ \\
\hline \multirow{3}{*}{ MC-LR } & 10.0 & 113.46 & 108.07 & 5.39 & 1.09 & 0.22 & 0.90 & 7.95 & \multirow{3}{*}{0.056} & \multirow{3}{*}{0.185} \\
\hline & 37.5 & 87.30 & 85.20 & 2.10 & 1.87 & 1.04 & 1.64 & 5.02 & & \\
\hline & 75.0 & 73.31 & 72.96 & 0.35 & 2.29 & 1.84 & 2.15 & 3.91 & & \\
\hline \multirow{3}{*}{ MC-RR } & 10.0 & 70.37 & 70.84 & -0.47 & 0.39 & 0.28 & 0.35 & 5.04 & \multirow{3}{*}{0.048} & \multirow{3}{*}{0.161} \\
\hline & 37.5 & 74.93 & 74.93 & 0 & 2.77 & 4.68 & 3.52 & 12.54 & & \\
\hline & 75.0 & 88.41 & 87.05 & 1.36 & 4.91 & 11.26 & 7.64 & 11.52 & & \\
\hline \multirow{3}{*}{ MC-YR } & 10.0 & 114.03 & 109.01 & 5.02 & 0.28 & 0.34 & 0.30 & 2.61 & \multirow{3}{*}{0.063} & \multirow{3}{*}{0.209} \\
\hline & 37.5 & 83.93 & 83.03 & 0.90 & 2.82 & 2.18 & 2.62 & 8.34 & & \\
\hline & 75.0 & 80.76 & 80.29 & 0.47 & 5.03 & 9.38 & 6.80 & 11.22 & & \\
\hline \multirow{3}{*}{ CYN } & 10.0 & 111.78 & 110.22 & 1.56 & 1.47 & 1.65 & 1.53 & 13.73 & \multirow{3}{*}{0.037} & \multirow{3}{*}{0.123} \\
\hline & 37.5 & 85.18 & 85.56 & -0.38 & 3.03 & 2.40 & 2.84 & 8.88 & & \\
\hline & 75.0 & 90.75 & 90.72 & 0.03 & 3.13 & 2.19 & 2.85 & 4.19 & & \\
\hline
\end{tabular}

Acceptable ranges for $\mathrm{RSD}_{\mathrm{AOAC}}(\%)$ : $16 \%$ for $10 \mathrm{ng} \mathrm{g}^{-1}$ f.w. and 8-16\% for 37.5 and $75 \mathrm{ng} \mathrm{g}^{-1}$ f.w. Acceptable ranges for Recovery $115 \%$ for all concentrations. 


\subsubsection{Matrix Effects}

The matrix effect could affect significantly the quantification, depending on different factors such as the composition and amount of matrix and the properties of the analyte (Li et al., 2014). The matrix effect was determined in mussels with the following expression: $\mathrm{ME}=100 \mathrm{x}$ [(slope matrix/slope solvent)-1], expressed in percentage. The values obtained were 28.28 for MC-LR, 17.77 for MC-RR, 18.97 for MC-YR and -11.26 for CYN, meaning mild matrix effect $(|10|<$ ME < |20|) for MC-RR, - YR and CYN, and medium $(|20|<M E<|50|)$ in the case of MC-LR. No strong matrix effects were observed in the present study. However, mild decreases in the responses of the cyanotoxins were detected: a decrease in the signal of MC-RR, similarly to Moreno et al. (2005) in fish, and in the response of CYN in agreement with Díez-Quijada et al. (2018) in vegetables. Moreover, a slight increase was observed in the response of MC-YR, in concordance with Ríos et al. (2013) in fish and crayfish. These effects could affect the ionization efficiency and weaken the analyte response. Therefore, matrix-matched calibration curves should be employed for quantification in order to obtaining more accurate results.

\subsection{Optimization procedures}

The yields obtained from the experimental runs were analyzed by RSM and the predicted values are shown in Table 2. The Mann-Whitney two-tailed test showed non-significant differences between the experimental and predicted values at a significance level of 0.001 . The multiple regression analysis of the RSM generated a system of 4 quadratic polynomial equations that proved to be good statistical models for the recovery yield of the toxins from a combined mixture (Table 3). They all had high coefficient of determination values $\left(\mathrm{R}^{2}\right)$ accounting for above $85 \%$ of the variability of the response (yields of the 4 toxins). 
Table 2. Recovery yield of the cyanotoxins at different extraction conditions based on a Box-Behnken design for response surface methodology (RSM).

\begin{tabular}{|c|c|c|c|c|c|c|c|c|c|c|c|}
\hline \multirow{3}{*}{$\begin{array}{l}\text { Sort } \\
\text { order }\end{array}$} & \multicolumn{3}{|c|}{ Extraction conditions - Independent variables } & \multicolumn{8}{|c|}{ Response - dependent variables } \\
\hline & \multirow{2}{*}{$\begin{array}{c}\mathrm{X}_{1} \\
\text { methanol } \\
\text { concentration } \\
(\% \mathrm{v} / \mathrm{v})\end{array}$} & \multirow{2}{*}{$\begin{array}{c}\mathrm{X}_{2} \\
\text { Sample- } \\
\text { solvent } \\
\text { ratio }(\mathrm{w} / \mathrm{v})\end{array}$} & \multirow{2}{*}{$\begin{array}{c}\mathrm{X}_{3} \\
\text { methanol } \\
\text { concentration } \\
\text { before SPE } \\
(\% \mathrm{v} / \mathrm{v})\end{array}$} & \multicolumn{2}{|c|}{$\begin{array}{c}\mathrm{Y}_{1} \text { MC-LR recovery yield } \\
(\%)\end{array}$} & \multicolumn{2}{|c|}{$\begin{array}{c}\mathrm{Y}_{2} \text { MC-RR recovery yield } \\
(\%)\end{array}$} & \multicolumn{2}{|c|}{$\begin{array}{c}\mathrm{Y}_{3} \mathrm{MC}-\mathrm{YR} \text { recovery yield } \\
(\%)\end{array}$} & \multicolumn{2}{|c|}{$\begin{array}{c}\mathrm{Y}_{4} \mathrm{CYN} \text { recovery yield } \\
(\%)\end{array}$} \\
\hline & & & & experimental & predicted* & experimental & predicted* & experimental & predicted* & experimental & predicted* \\
\hline 1 & 80 & 25 & 15 & 60.66 & 58.98 & 70.30 & 70.886 & 74.03 & 72.099 & 100.49 & 95.22 \\
\hline 2 & 90 & 50 & 15 & 78.49 & 74.39 & 91.91 & 83.637 & 82.53 & 80.623 & 102.37 & 96.35 \\
\hline 3 & 100 & 50 & 25 & 69.32 & 69.40 & 65.61 & 66.734 & 74.98 & 75.610 & 95.78 & 88.06 \\
\hline 4 & 80 & 50 & 25 & 52.85 & 48.13 & 56.13 & 49.114 & 63.94 & 61.038 & 65.11 & 66.52 \\
\hline 5 & 100 & 25 & 15 & 91.29 & 84.82 & 85.00 & 77.446 & 92.99 & 87.526 & 96.84 & 100.69 \\
\hline 6 & 80 & 50 & 5 & 45.94 & 45.86 & 40.83 & 39.706 & 57.94 & 57.310 & 45.10 & 52.82 \\
\hline 7 & 90 & 25 & 25 & 71.21 & 77.61 & 77.29 & 83.720 & 77.27 & 82.104 & 96.51 & 100.38 \\
\hline 8 & 90 & 50 & 15 & 68.59 & 74.39 & 81.74 & 83.637 & 76.15 & 80.623 & 93.75 & 96.35 \\
\hline 9 & 90 & 25 & 5 & 69.97 & 71.72 & 80.77 & 81.308 & 75.12 & 77.681 & 89.33 & 86.89 \\
\hline 10 & 90 & 75 & 25 & 78.81 & 77.06 & 96.02 & 95.483 & 85.91 & 83.349 & 92.06 & 94.50 \\
\hline 11 & 90 & 50 & 15 & 76.10 & 74.39 & 77.26 & 83.637 & 83.19 & 80.623 & 92.94 & 96.35 \\
\hline 12 & 100 & 75 & 15 & 83.57 & 85.25 & 98.89 & 98.304 & 88.46 & 90.391 & 119.82 & 125.10 \\
\hline 13 & 90 & 75 & 5 & 86.73 & 80.34 & 90.54 & 84.110 & 86.93 & 82.096 & 98.88 & 95.01 \\
\hline 14 & 80 & 75 & 15 & 60.15 & 66.62 & 57.04 & 64.594 & 69.43 & 74.894 & 76.91 & 73.06 \\
\hline 15 & 100 & 50 & 5 & 64.34 & 69.06 & 55.34 & 62.356 & 70.76 & 73.663 & 90.19 & 88.78 \\
\hline \multicolumn{4}{|c|}{ p-value** } & \multicolumn{2}{|c|}{0.935} & \multicolumn{2}{|c|}{0.967} & \multicolumn{2}{|c|}{1.000} & \multicolumn{2}{|c|}{0.775} \\
\hline
\end{tabular}

*the predicted value resulted from the model optimizing the simultaneous extraction of the 4 toxins.

**Mann-Whitney two-tailed test $(\alpha=0.001)$ of the experimental data versus the yields predicted by the model optimizing the simultaneous extraction of the 4 toxins. 
The differences between root mean square error (RMSE) and predicted residual error sum of squares (Press's) RMSE were small, showing that the model was not sensitive to the presence or absence of specific observations in the model. Additionally, the $\mathrm{Q}^{2}$ (1- (Press's RMSE)/(sum of the squares of the errors) for the model) values were close to 1 , suggesting that the model is good and robust. The statistical models were better for MC-RR and CYN recovery which had $\mathrm{R}^{2}$ values above $90 \%$ and both reached statistical significance.

Table 3. Model parameters (coded coefficients) and goodness of fit statistics obtained by response surface methodology (RSM) for each of the four response variables (Yi).

\begin{tabular}{|c|c|c|c|c|c|}
\hline & & $\begin{array}{c}\mathrm{Y}_{1} \\
\text { MC-LR recovery }\end{array}$ & $\begin{array}{c}\mathrm{Y}_{2} \\
\text { MC-RR recovery }\end{array}$ & $\begin{array}{c}\mathrm{Y}_{3} \\
\text { MC-YR recovery }\end{array}$ & $\begin{array}{c}\mathrm{Y}_{4} \\
\text { CYN recovery }\end{array}$ \\
\hline \multicolumn{6}{|c|}{ Coefficient } \\
\hline \multirow[t]{2}{*}{ intercept } & b0 & 74.39 & 83.64 & 80.62 & 96.35 \\
\hline & b1 & $11.12^{* * *}$ & $10.07^{* *}$ & $7.73^{* *}$ & $14.38^{* * *}$ \\
\hline \multirow[t]{3}{*}{ linear } & b2 & 2.02 & 3.64 & 1.42 & 0.56 \\
\hline & b3 & 0.65 & 3.45 & 1.42 & 3.25 \\
\hline & b11 & $-9.52^{*}$ & $-18.75^{* *}$ & $-6.90^{*}$ & $-8.99^{*}$ \\
\hline \multirow[t]{3}{*}{ quadratic } & b22 & $9.05^{*}$ & $12.92^{* *}$ & $7.50^{*}$ & $11.16^{* *}$ \\
\hline & b33 & $-6.76^{*}$ & $-10.41^{*}$ & $-6.82^{*}$ & $-13.31^{* *}$ \\
\hline & b12 & -1.80 & 6.79 & 0.02 & $11.64^{* *}$ \\
\hline \multirow[t]{2}{*}{ interaction } & b13 & -0.48 & -1.26 & -0.45 & -3.61 \\
\hline & b23 & -2.29 & 2.24 & -0.79 & -3.50 \\
\hline \multicolumn{2}{|c|}{$\mathrm{R}^{2}$} & 0.87 & 0.90 & 0.86 & 0.93 \\
\hline \multicolumn{2}{|c|}{$\mathrm{p}$-value } & $0.075^{*}$ & $0.047^{* *}$ & $0.090^{*}$ & $0.022^{* *}$ \\
\hline \multicolumn{2}{|c|}{ RMSE } & 20.94 & 28.54 & 16.00 & 28.93 \\
\hline \multicolumn{2}{|c|}{ Press RMSE } & 27.09 & 31.74 & 21.83 & 28.73 \\
\hline \multicolumn{2}{|c|}{$\mathrm{Q}^{2}$} & -0.67 & -0.24 & -0.86 & 0.01 \\
\hline
\end{tabular}

${ }^{*}$ Significant at $\mathrm{P}<0.15,{ }^{* *}$ Significant at $\mathrm{P}<0.05,{ }^{* * *}$ Significant at $\mathrm{P}<0.01$.

The $\mathrm{MeOH}$ concentration $(\% \mathrm{v} / \mathrm{v})$ of the solvent for extraction had the greatest statistically significant influence upon the recovery yields of the 4 toxins. The positive linear coefficients showed that a high concentration of $\mathrm{MeOH}$ seems to generally increase recovery 
yields, especially for the most hydrophobic MCs. However, the negative quadratic coefficients suggest that there is a maximum limit of $\mathrm{MeOH}$ concentration for optimal recovery, as seen in the plots obtained by RSM, and this could be the case for the more hydrophilic MC-RR and especially CYN (Figure 2).

A significant positive interaction was found between the $\mathrm{MeOH}$ concentrations for extraction and the $\mathrm{MeOH}$ percentage of the extract for loading onto SPE only in the case of CYN. That means that the chosen concentration of $\mathrm{MeOH}$ for the extraction will influence the optimal $\% \mathrm{MeOH}$ for loading onto SPE.
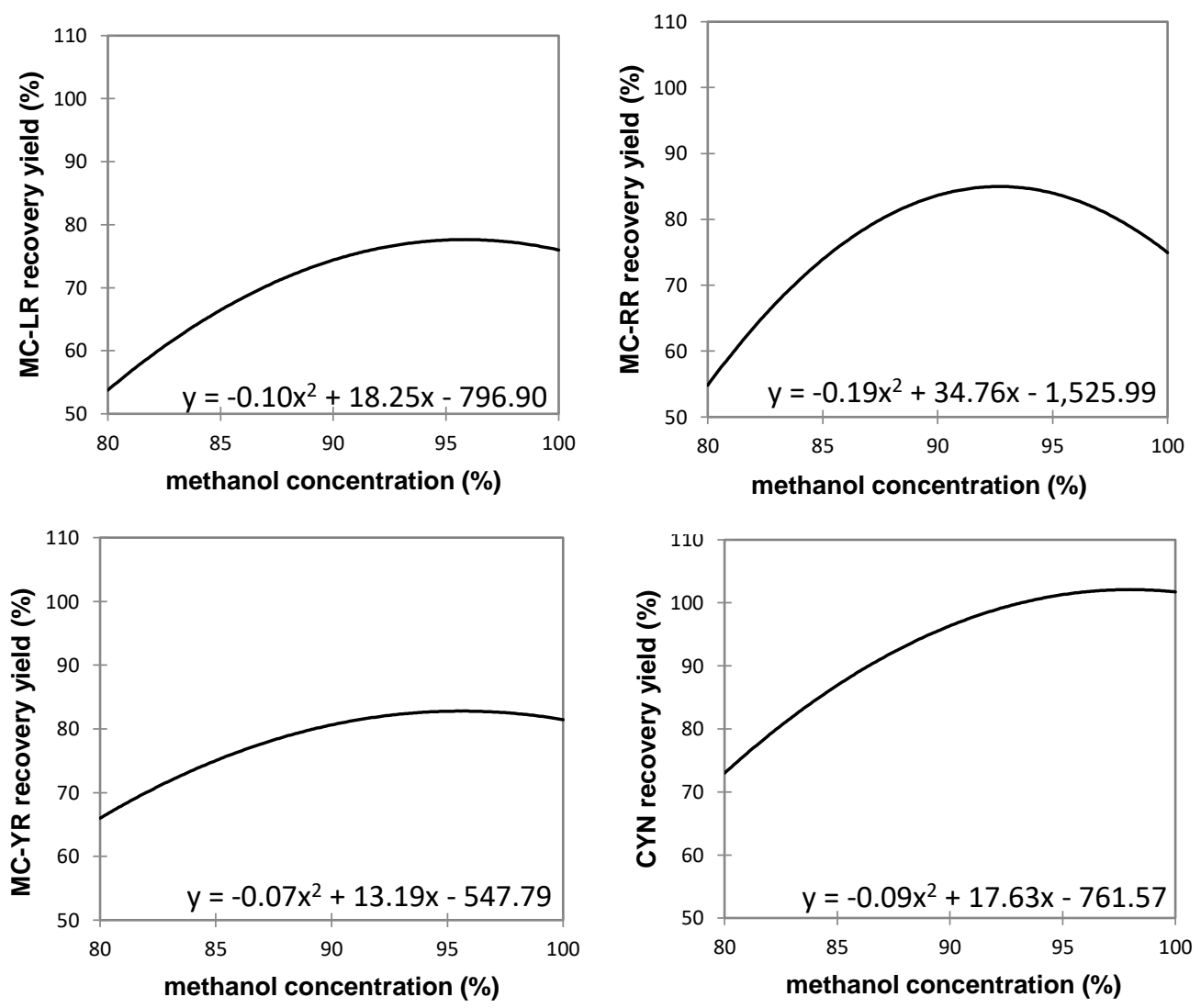

Figure 2. Effect of the $\mathrm{MeOH}$ concentration (\% v/v) of the solvent for the extraction on the recovery yield of cyanotoxins from complex mixtures.. 
Thus, the present model shows that the maximum yields should be obtained at the following concentrations: $91.25 \%$ for MC-LR; $91.47 \%$ for MC-RR; $94.21 \%$ for MC-YR and 97.94\% for CYN, when considering a $\mathrm{MeOH}$ concentration between $80 \%$ and $100 \%$. This is in agreement with other authors who reported optimal recoveries when using $75-90 \% \mathrm{MeOH}$ for MCs extraction from fish or mussel tissues (Karlsson et al., 2005; Moreno et al., 2005; Mekebri et al., 2009; Smith and Boyer, 2009; Manubolu et al., 2018; Turner et al., 2018). According to Turner et al. (2018), lower recoveries were observed by the use of concentrations below $70 \%$ $\mathrm{MeOH}$.

A higher solvent/sample ratio in the extraction seems to positively influence the recovery yields of the 4 toxins, but the linear regression coefficients did not reach statistical significance (Table 3). The positive influence of the quadratic coefficients was statistically confirmed, thus explaining the presence of the linear coefficients in the hierarchical model (Table 3). However, the quadratic regression showed the presence of 2 possible maximum optimal ratios depending on the position of the minimum with the tested 25-75 solvent to sample ratio interval (Figure 3 ). The tested solvent to sample ratio interval 25 to 75 was selected as following the preliminary tests and as indicated by the scientific literature in either fish or mollusks (Guzmán-Guillén et al., 2011, 2015; Freitas et al., 2014, 2016). In addition, a higher ratio would imply a higher consumption of extraction solvent, thus a wasteful approach as the solvent is evaporated almost entirely prior to analysis. Moreover, a lower ratio would make more difficult the manipulation and further extraction of the 4 cyanotoxins. 

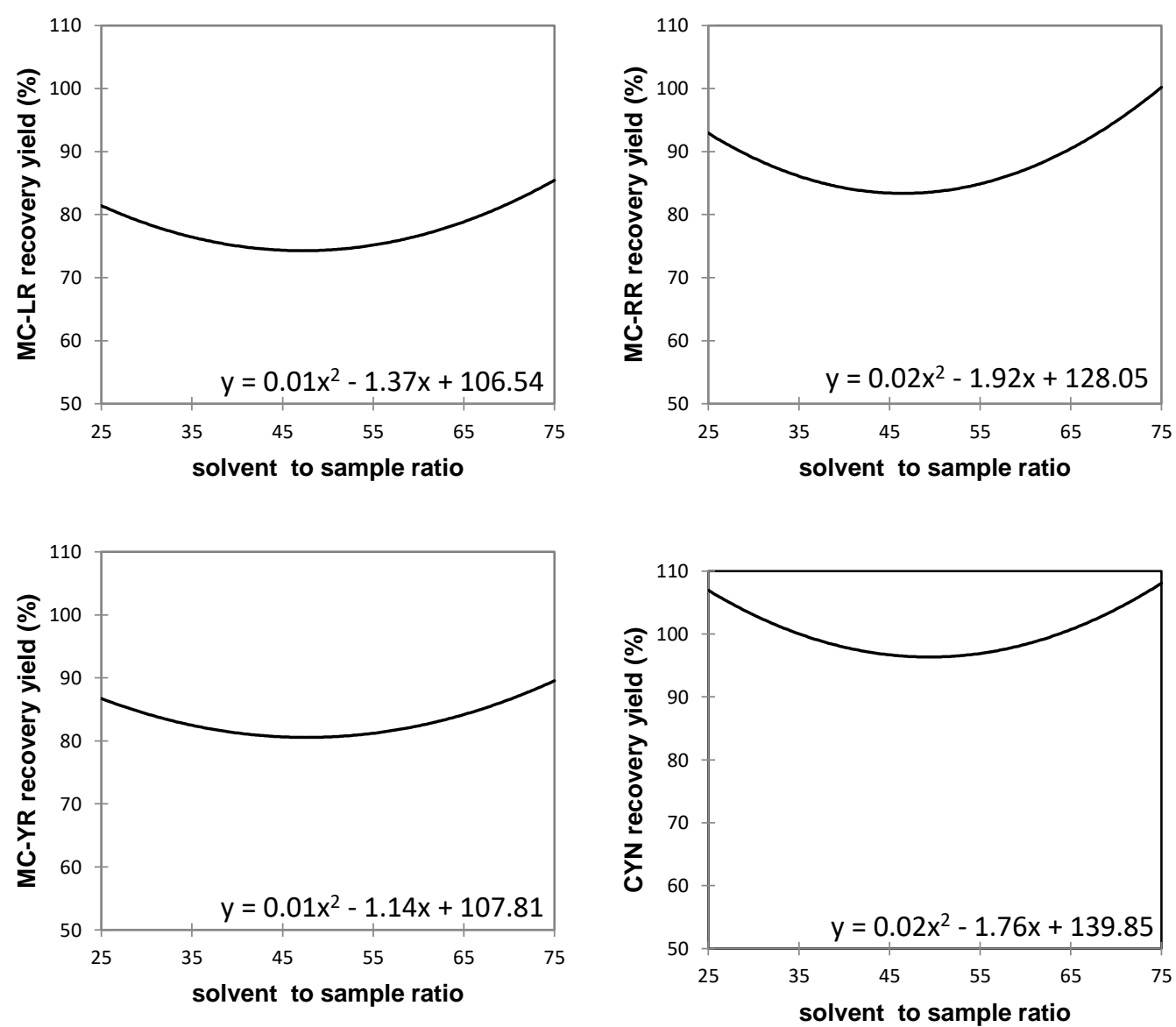

Figure 3. Effect of solvent/sample ratio in the extraction on the recovery yield of cyanotoxins from complex mixtures.

Thus, when determining the maximum yields of the 4 toxins from this model the 75 emerges as the optimal solvent/sample ratios within the range of 25 to 75 .

The positive linear regression coefficients (Table 3) appeared to indicate that a higher $\mathrm{MeOH}$ concentration of the extract for loading onto SPE slightly increased the recovery yield of the 4 toxins. But, the higher quadratic coefficients, statistically significant, showed that there might be a maximum optimal concentration, as seen in the plots obtained by RSM (Figure 4). Although their significance was not confirmed statistically, the linear coefficients were 
maintained within the model because of its hierarchical nature. This effect was consistent to that observed for the MeOH concentration used for loading onto SPE (Greer et al., 2016).
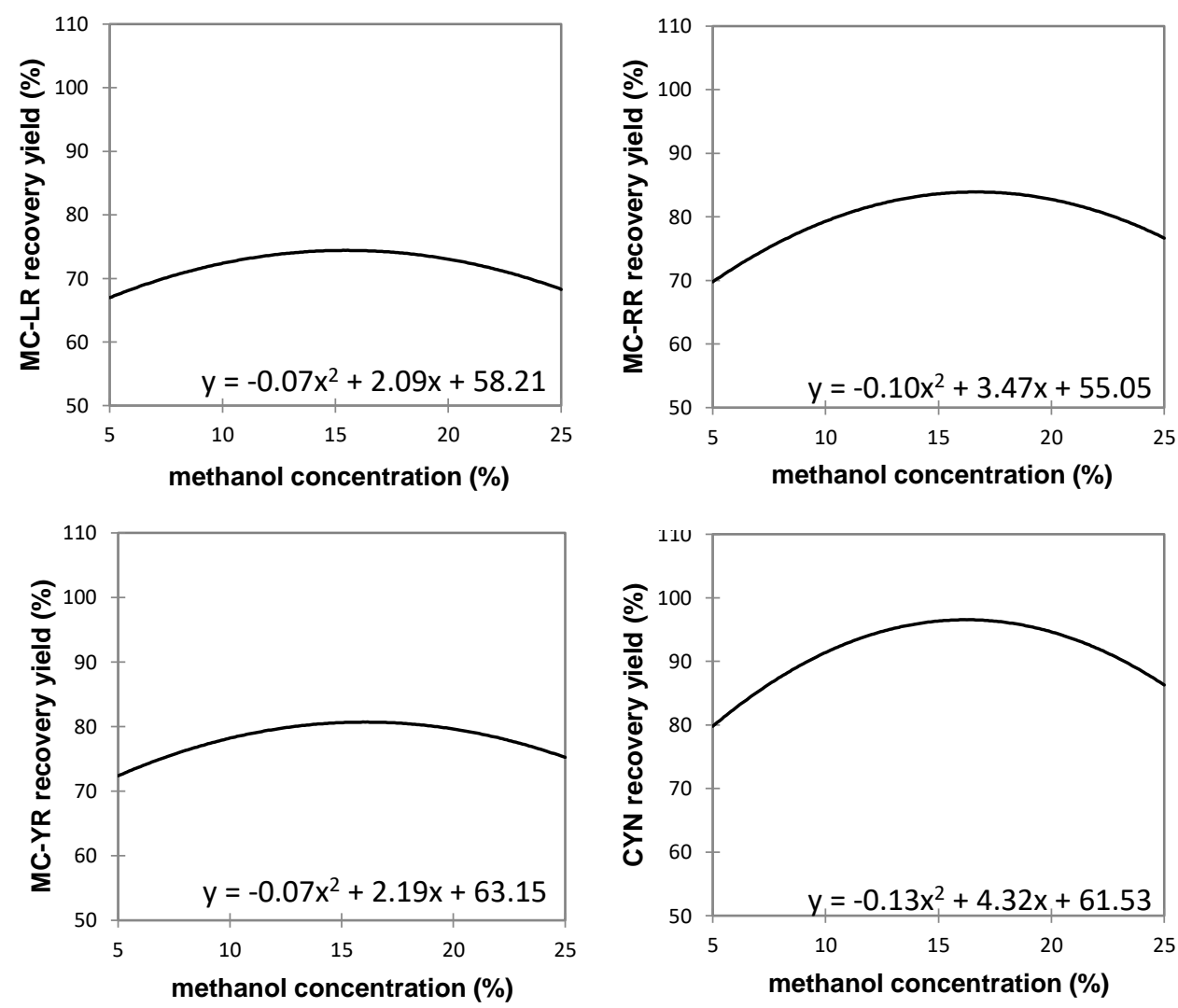

Figure 4. Effect of $\mathrm{MeOH}$ concentration for loading onto the solid phase extraction (SPE) (\% v/v) on the recovery yield of cyanotoxins from complex mixtures.

In conclusion, our model suggests that the maximum yields might be obtained at the following concentrations of $\mathrm{MeOH}$ in the extracts for loading onto SPE: $14.92 \%$ for MC-LR; $17.35 \%$ for MC-RR; $15.64 \%$ for MC-YR and $16.61 \%$ for CYN, when considering a concentration interval of $5 \%$ to $25 \%$. This is consistent with the desirability the plots obtained by RSM (Figure 5). 

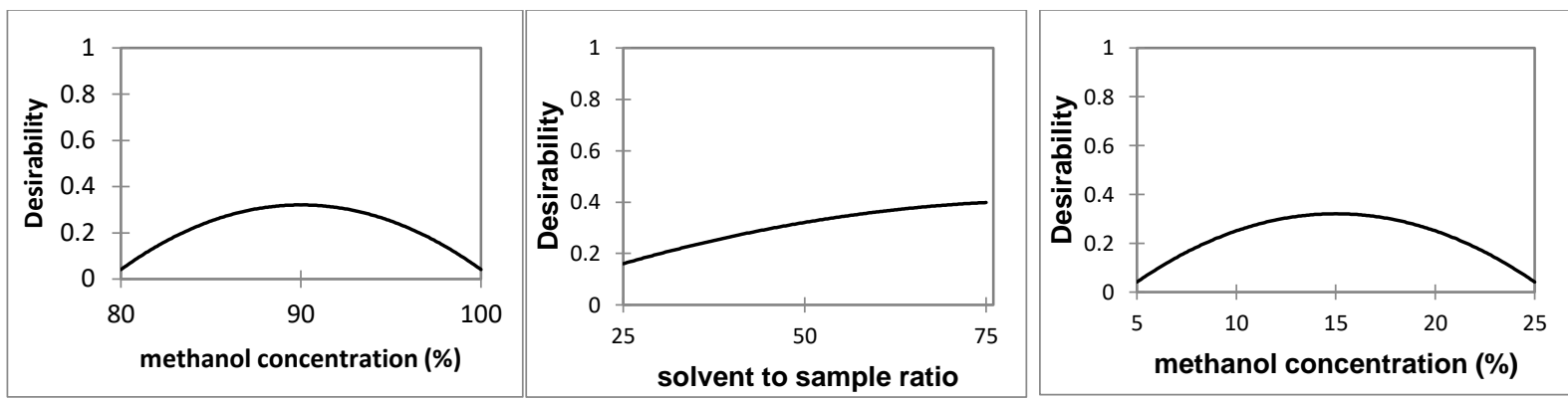

Figure 5. Desirability plots of the 3 independent variables: $\mathrm{MeOH}$ concentration $(\% \mathrm{v} / \mathrm{v})(\mathrm{X} 1)$ of the solvent used for extraction, solvent/sample ratio (X2) and $\mathrm{MeOH}$ concentration of the extract for loading onto SPE $(\% \mathrm{v} / \mathrm{v})$.

By using the BBD the number of experiments was significantly reduced compared to the fully factorial design with 3 levels, which would have generated a number of 27 experiments. In addition, less extreme experimental combinations were obtained than $\mathrm{CCD}$. In this way, a smaller number of experimental combinations was able to generate sufficiently reliable results. By using the RSM and desirability analysis we were able to determine the mathematical optimum of the 3 extraction parameters within the ranges proposed. Thus, based on the results obtained in the RSM optimization study for the simultaneous extraction conditions of MC-LR, MC-RR, MC-YR and CYN from mussels, the following optimum parameters were chosen for further model validation: $90 \% \mathrm{MeOH}$ concentration $(\% \mathrm{v} / \mathrm{v})$ for the extraction, a 75 solvent/sample ratio and $15 \% \mathrm{MeOH}$ in the extract for loading onto SPE.

\subsection{Accuracy Study: Precision and Trueness}

The measurement uncertainty includes three concepts: repeatability, intermediate precision and reproducibility (Barwick, 2016). The type of precision performed in the present study deals with intra-laboratory assays, so reproducibility was not assessed. The values for repeatability $\left(S_{\mathrm{W}}\right.$ or within-day and $\mathrm{S}_{\mathrm{B}}$ or between-day repeatability), intermediate precision $\left(\mathrm{S}_{\mathrm{IP}}\right)$, and $\mathrm{S}_{\mathrm{IP}}$ relative standard deviations $\left(\% \mathrm{RSD}_{\mathrm{IP}}\right)$ were calculated by analysis of three replicates of 
mussels extracts spiked with the standard mixture solution containing MC-LR, MC-RR, MC-YR and CYN at different concentrations or validation standards $\left(10 ; 37.5\right.$; and $\left.75 \mathrm{ng} \mathrm{g}^{-1} \mathrm{f} . \mathrm{w}.\right)$ on the same day, and on three different days following the ICH guidelines (ICH, 2005). These three different days represent the main source of variation, and the estimations of these precision parameters were obtained by performing ANOVA for each validation standard according to González et al. (2010) and González and Herrador (2007). The relative standard deviations $\left(\% \mathrm{RSD}_{\mathrm{IP}}\right)$ obtained for each toxin were compared with the acceptable RSD values obtained from the AOAC Peer Verified Methods Program (AOAC, 2016) according to the concentration level of analyte assayed (16\% for $10 \mathrm{ng} \mathrm{g}^{-1}$ f.w. or $8-16 \%$ for 37.5 and $75 \mathrm{ng} \mathrm{g}^{-1}$ f.w.). The $\%$ RSDIP values presented for the cyanotoxins at the three concentration levels assayed were lower or in the range specified by AOAC tabulated values, thus the proposed method can be considered as precise (Table 1).

Trueness is the closeness of agreement between a test result and the accepted reference value of the property being measured and it can be investigated by spiking and recovery (Magnusson and Örnemark, 2014). The recovery yields obtained in the current study are presented in Table 1, and they were all acceptable in accordance to the tabulated values of 60-115\% (González et al., 2010). It seems that recovery yields were better for CYN, followed by MC-LR or MC-YR and finally, for MC-RR. However, all of them were satisfactory despite the differences. These results are comparable or even better than the yields (>94\%) reported for MC-LR and MC-RR from fish tissues (Manubolu et al., 2018). Turner et al. (2018) showed similar recovery yields from mussel samples for MC-LR and MC-YR, but those for MC-RR were a slightly higher than in the present work. The differences could be explained by the $80 \% \mathrm{MeOH}$ used as solvent by the authors, which could extract better the more hydrophilic MC congener. However, in our 
experiment an optimal $90 \% \mathrm{MeOH}$ was chosen for the simultaneous extraction of the cyanotoxins. Additionally, CYN proved to have the highest recovery yields of the four tested cyanotoxins in similar validation studies in other matrices, such as lettuce (Díez-Quijada et al., 2018).

\subsection{RSM model validation}

Predicted recovery values were obtained after computing the model for each toxin and compared with the experimental data. As it can be observed in Table 1, there are no statistical differences between them, with a $\mathrm{R}^{2}=0.994$ (level of confidence $\mathrm{p}<0.001$ ), so the model was validated.

\subsection{Application to mussel samples}

The validated method was finally applied to mussel samples exposed in aquaria to cyanobacterial cultures producers of MC-LR and CYN, as explained in section 2.7. LOD and LOQ values obtained for the present method allow the detection of these two cyanotoxins in the mussels. Levels of CYN and MC-LR detected in mussels sampled after the 14-day exposure period, and after the depuration phase are presented in Figure 6.

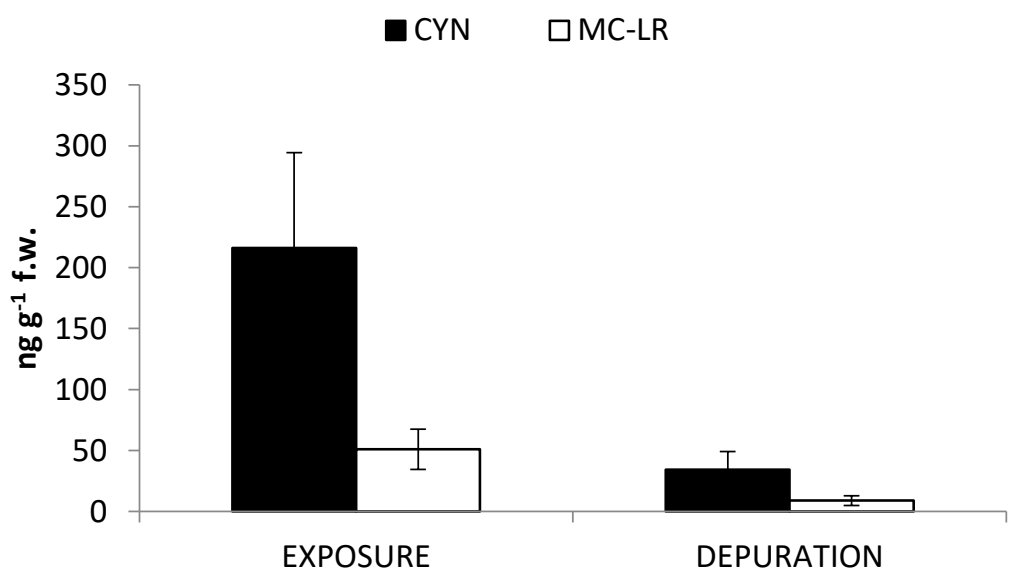


Figure 6. Levels of CYN and MC-LR detected in mussels after exposure to cultures of M. aeruginosa and C. ovalisporum for 14 days (exposure phase) and after a depuration phase of 14 additional days.

\section{Conclusions}

This study presents for the first time a method for the simultaneous extraction and determination of MCs (MC-LR, MC-RR, and MC-YR) and CYN. It was optimized in mussels by RSM and validated by SPE-UPLC-MS/MS, reporting adequate linearity and sensitivity, precision and recovery yields for the considered cyanotoxins. This method was satisfactorily applied to mussel samples for human consumption, suggesting its possible application in the monitoring of simultaneous presence of MCs and CYN in this food and allowing the acquisition of exposure data for risk assessment.

\section{Conflict of Interest}

The authors declare that there are no conflicts of interest.

\section{Acknowledgements}

This work was funded by the Spanish Ministry of Economy and Competitiveness (project AGL2015-64558-R, MINECO/FEDER, UE; and grant number BES-2016-078773 awarded to Leticia Díez-Quijada Jiménez); the EFSA funding under the EU-FORA Programme of Giorgiana M. Cătunescu; and Projects MOREBIVALVES (PTDC/ASP-PES/31762/2017) and UID/Multi/04423/2013 co-financed by NORTE 2020, Portugal 2020 and the European Union through the ERDF, and by Portuguese Science Foundation (Fundação para a Ciência e a Tecnologia, FCT). 


\section{References}

Addinsoft, 2019. XLSTAT statistical and data analysis solution. Long Island, NY, USA. https://www.xlstat.com. (accessed on 10 February 2020).

Anderson, L., Fabbro, L.D., Cowden, K., 2003. Assessment of Blue-Green Algal Toxins in Barramundi, Red Clay and Mussels from Awoonga Dam. Central Queensland University, Gladstone, Australia.

Anuar, N., Mohd Adnan, A.F., Saat, N., Aziz, N., Mat Taha, R., 2013. Optimization of Extraction Parameters by Using Response Surface Methodology, Purification, and Identification of Anthocyanin Pigments in Melastoma malabathricum Fruit. Sci. World J. 2013, 1-10. doi:10.1155/2013/810547.

Amorim, Á., Vasconcelos, V., 1999. Dynamics of microcystins in the mussel Mytilus galloprovincialis. Toxicon 37, 1041-1052. https://doi.org/10.1016/S0041-0101(98)00231-1.

AOAC International; AOAC Official Methods of Analysis. Guidelines for Standard Method Performance Requirements; Appendix F; AOAC International: Rockville, MD, USA, 2016; Available online: http://www.eoma.aoac.org/app_f.pdf.

Bagu, J.R., Sykes, B.D., Craig, M.M, Holmes, C.F., 1997. A molecular basis for different interactions of marine toxins with protein phosphatase-1. Molecular models for bound motuporin, microcystins, okadaic acid, and calyculin A. J. Biol. Chem. 272, 5087-5097. DOI: 10.1074/jbc.272.8.5087.

Baralla, E., Varoni M.V., Sedda, T., Pasciu, V., Floris, A., Demontis, M.P., 2017. Microcystins Presence in Mussels (M. galloprovincialis) and Water of Two Productive Mediterranean's Lagoons (Sardinia, Italy). Biomed. Res. Int. 1-7. https://doi.org/10.1155/2017/3769245.

Barwick, V., (Ed), Eurachem/CITAC Guide: Guide to Quality in Analytical Chemistry: An Aid to Accreditation ( $3^{\text {rd }}$ ed. 2016). ISBN 978-0-948926-32-7. Available from www.eurachem.org. 
Buratti, F.M., Manganelli, M., Vichi, S., Stefanelli, M., Scardala, S., Testai, E., Funari, E., 2017. Cyanotoxins: producing organisms, occurrence, toxicity, mechanism of action and human health toxicological risk evaluation. Arch. Toxicol. 91, 1049-1130. https://doi.org/10.1007/s00204-0161913-6.

Cameán, A.M., Moreno, I.M., Ruiz, M.J., Picó, Y., 2004. Determination of microcystins in natural blooms and cyanobacterial strains cultures by matrix solid-phase dispersion and liquid chromatography-mass spectrometry. Anal. Bioanal. Chem. 380, 537-544. https://doi.org. 10.1007/s00216-004-2755-2.

Cao, Q., Liu, W., Jiang, W., Shu, X., Xie, L., 2019. Glutathione biosynthesis plays an important role in microcystin-LR depuration in lettuce and spinach. Environ. Pollut. 253, 599-605. https://doi.org/10.1016/j.envpol.2019.07.064.

Chiswell, R.K., Shaw, G.R., Eaglesham, G., Smith, M.J., Norris, R.L., Seawright, A.A., Moore, M.R., 1999. Stability of cylindrospermopsin, the toxin from the cyanobacterium, Cylindrospermopsis raciborskii: Effect of $\mathrm{pH}$, temperature, and sunlight on decomposition. Environ. Toxicol. 14, 155-161. https://doi.org/10.1002/(SICI)15227278(199902)14:1<155::AID-TOX20>3.0.CO;2-Z.

Chorus, I., Bartram, J., 1999. Toxic cyanobacteria in water: a guide to their public health consequences, monitoring and management. World Health Organization, Geneva (ISBN 0-41923930-8).

Diez-Quijada, L., Guzmán-Guillén, R., Prieto-Ortega, A.I., Llana-Ruiz-Cabello, M., Campos, A., Vasconcelos, V., Jos, A., Cameán, A.M., 2018. New method for simultaneous determination of Microcystins and Cylindrospermopsin in vegetable matrices by SPE-UPLC-MS/MS. Toxins 10, 406-421. https://doi:10.3390/toxins10100406. 
Diez-Quijada, L., Puerto, M., Gutiérrez-Praena, D., Llana-Ruiz-Cabello, M., Jos, A., Cameán, A.M., 2019a. Microcystin-RR: Occurrence, content in water and food and toxicological studies. A review. Environ. Res. 168, 467-489. https://doi.org/10.1016/j.envres.2018.07.019.

Diez-Quijada, L., Llana-Ruiz-Cabello, M., Cătunescu, M.G., Puerto, M., Moyano, R., Jos, A., Cameán, A.N., 2019b. In vivo genotoxicity evaluation of cylindrospermopsin in rats using a combined micronucleus and comet assay. Food Chem. Toxicol. 132, 110664. https://doi.org/10.1016/j.fct.2019.110664.

Diez-Quijada, L., Prieto, A.I., Guzmán-Guillén, R., Jos, A., Cameán, A.M., 2019c. Occurrence and toxicity of microcystin congeners other than MC-LR and MC-RR: A review. Food Chem. Toxicol. 125, 106-132. https://doi.org/10.1016/j.fct.2018.12.042.

El Ghazali, I., Saqrane, S., Carvalho, A.P., Ouahid, Y., Del Campo, F.F., Oudra, B., Vasconcelos, V., 2010. Effect of different microcystin profiles on toxin bioaccumulation in common carp (Cyprinus carpio) larvaevia Artemia nauplii. Ecotoxicol. Environ. Saf. 73, 762770. https://doi.org/10.1016/j.ecoenv.2009.12.015.

Ferreira, S.L.C., Bruns, R.E., Ferreira, H.S., Matos, G.D., David, J.M., Brandão, G. C., Da Silva, E.G.P., Portugal, L.A., Dos Reis, P.S., Souza, A.S., Dos Santos, W. N. L., 2007. Box-Behnken design: An alternative for the optimization of analytical methods. Anal. Chim. Acta 597, 179186. https://doi.org/10.1016/j.aca.2007.07.011.

Freitas, M., Azevedo, J., Carvalho, A.P., Campos, A., Vasconcelos, V., 2014. Effects of storage, processing and proteolytic digestion on microcystin-LR concentration in edible clams. Food Chem. Toxicol. 66, 217-223. https://doi.org/10.1016/j.fct.2014.01.041.

Freitas, M., Azevedo, J., Carvalho, A.P., Mendes, V.M., Manadas, B., Campos, A., Vasconcelos, V., 2016. Bioaccessibility and changes on cylindrospermopsin concentration in edible mussels with storage and processing time. Food Control 59, 567-574. https://doi.org/10.1016/j.foodcont.2015.06.025. 
Funari, E., Manganelli, M., Buratti, F.M., Testai, E., 2017. Cyanobacteria blooms in water: Italian guidelines to assess and manage the risk associated to bathing and recreational activities. Sci. Total Environ. 598, 867-880. http://dx.doi.org/10.1016/j.scitotenv.2017.03.232.

García, A.C., Bargu, S., Dash, P., Rabalais, N.N., Sutor, M., Morrison, W., Walker, N.D., 2010. Evaluating the potential risk of microcystins to blue crab (Callinectes sapidus) fisheries and human health in a estuary. http://dx.doi.org/10.1016/j.fct.2013.03.025doi:10.1016/j.hal.2009.08.011.

García Nieto, P.J., Alonso Fernández, J.R., de Cos Juez, F.J., Sánchez Lasheras, F., Díaz Muñiz, C., 2013. Hybrid modelling based on support vector regression with genetic algorithms in forecasting the cyanotoxins presence in the Trasona reservoir (Northern Spain). Environ. Res. 122, 1-10. http://dx.doi.org/10.1016/j.envres.2013.01.001.

Gibble, C. M., Peacock, M. B., Kudela, R. M., 2016. Evidence of freshwater algal toxins in marine shellfish: Implications for human and aquatic health. Harmful Algae 59, 59-66. https://doi.org/10.1016/j.hal.2016.09.007.

Gkelis, S., Lanaras, T., Sivonen, K., 2006. The presence of microcystins and other cyanobacterial bioactive peptides in aquatic fauna collected from Greek freshwaters. Aquat. Toxicol. 78, 32-41. https://doi.org/10.1016/j.aquatox.2006.02.001.

González, A.G., Herrador, M.A., 2007. A practical guide to analytical method validation, including measurement uncertainty and accuracy profiles. Trends Anal. Chem. 26, 227-238. https://doi.org/10.1016/j.trac.2007.01.009.

González, A.G., Herrador, M.A., Asuero, A.G., 2010. Intra-laboratory assessment of method accuracy (trueness and precision) by using validation standards. Talanta 82, 1995-1998. https://doi.org/10.1016/j.talanta.2010.07.071. 
Greer, B., McNamee, S.E., Boots, B., Cimarelli, L., Guillebault, D., Helmi, K., Marcheggiani, S., Panaiotov, S., Breitenbach, U., Akçaalan, R., Medlin, L.K., Kittler, K., Elliott, C.T., Campbell, K., 2016. A validated UPLC-MS/MS method for the surveillance of ten aquatic biotoxins in European brackish and freshwater systems. Harmful Algae 55, 31-40. https://doi.org/10.1016/j.hal.2016.01.006.

Greer, B., Meneely, J.P., Elliott, C.T., 2018. Uptake and accumulation of Microcystin-LR based on exposure through drinking water: An animal model assessing the human health risk. Sci. Rep. 8, 4913. DOI: 10.1038/s41598-018-23312-7.

Gutiérrez-Praena, D., Jos, A., Pichardo, S., Moreno, I.M., Cameán, A.M., 2013. Presence and bioaccumulation of microcystins and cylindrospermopsin in food and the effectiveness of some cooking techniques at decreasing their concentrations: a review. Food Chem. Toxicol. 53, 139152. https://doi.org/10.1016/j.fct.2012.10.062.

Guzmán-Guillén, R., Prieto, A. I., Moreno, I., Soria, M. E., Cameán, A. M., 2011. Effects of thermal treatments during cooking, microwave oven and boiling, on the unconjugated microcystin concentration in muscle of fish (Oreochromis niloticus). Food Chem. Toxicol. 49, 2060-2067. https://doi.org/10.1016/j.fct.2011.05.018.

Guzmán-Guillén, R., Prieto, A.I., Gónzalez, A.G., Soria-Díaz, M.E., Cameán, A.M., 2012a. Cylindrospermopsin determination in water by LC-MS/MS: Optimization and validation of the method and application to real samples. Environ. Toxicol. Chem. 31, 2233-2238. https://doi.org/ 10.1002/etc.1954.

Guzmán-Guillén, R., Prieto Ortega, A.I., Moreno, I., González, G., Soria-Díaz, M.E., Vasconcelos, V., Cameán, A.M., 2012b. Development and optimization of a method for the determination of Cylindrospermopsin from strains of Aphanizomenon cultures: Intra-laboratory assessment of its accuracy by using validation standards. Talanta 100, 356-363. https://doi.org/10.1016/j.talanta.2012.07.087. 
Guzmán-Guillén, R., Moreno, I.M., Prieto, A.I., Soria-Díaz, M.E., Vasconcelos, V.M., Cameán, A.M., 2015. CYN determination in tissues from freshwater fish by LC-MS/MS: Validation and application in tissues from subchronically exposed tilapia (Oreochromis niloticus). Talanta 131, 452-459. https://doi.org/10.1016/j.talanta.2014.07.091.

Guzmán-Guillén, R., Maisanaba, S., Prieto Ortega, A.I., Valderrama-Fernández, R., Jos, A., Cameán, A.M., 2017. Changes on cylindrospermopsin concentration and characterization of decomposition products in fish muscle (Oreochromis niloticus) by boiling and steaming. Food Control 77, 210-220. https://doi.org/10.1016/j.foodcont.2017.02.035.

Harada, K., Matsuura, K., Suzuki, M., Watanabe, M.F., Oishi, S., Dahlem, A.M., Beasley, V.R,, Carmichael, W.W., 1990. Isolation and characterization of the minor components associated with microcystins LR and RR in the cyanobacterium (blue-green algae). Toxicon 28(1), 55-64. https://doi.org/10.1016/0041-0101(90)90006-S.

Hooser, S. B., Kuhlenschmidt, M. S., Dahlem, A. M., Beasley, V. R., Carmichael, W. W., Haschek, W. M., 1991. Uptake and subcellular localization of tritiated dihydro-microcystin-LR in rat liver. Toxicon 29(6), 589-601. DOI: 10.1016/0041-0101(91)90053-t.

Huber, L., 1998. Validation and Qualification in Analytical Laboratories; Interpharm: East Englewood, CO, USA, pp. 1-288. ISBN 9780849382673.

Humpage, A.R., Falconer, I.R., 2003. Oral toxicity of the cyanobacterial toxin cylindrospermopsin in male Swiss albino mice: Determination of no observed adverse effect level for deriving a drinking water guideline value. Environ. Toxicol. 18, 94-103. https://doi.org/10.1002/tox.10104.

Ibelings, B.W., Chorus, I., 2007. Accumulation of cyanobacterial toxins in freshwater "seafood" and its consequences for public health: a review. Environ. Pollut. 150, 177-192. https://doi.org/10.1016/j.envpol.2007.04.012. 
ICH Harmonised Tripartite Guideline, 2005. Validation of analytical procedures: Text and methodology Q2(R1). ICH Working Group. Available online: http://www.ich.org/fileadmin/Public_Web_Site/ICH_Products/Guidelines/Quality/Q2_R1/Step4/ Q2_R1_Guideline.pdf. (accessed on 10 February 2020).

Karlsson, K.M., Spoof, L.E.M., Meriluoto, J.A.O., 2005. Quantitative LC-ESI-MS analyses of microcystins and Nodularin-R in animal tissue - matrix effects and method validation. Environ. Toxicol. 20, 381-389. https://doi.org/10.1002/tox.20115.

Kim, M.S., Lee, Y., Ha, S.Y., Kim, B.H., Hwang, S.J., Kwon, J.T., Choi, J.W., Shin, K.H., 2017. Accumulation of microcystin (LR, RR and YR) in three freshwater bivalves in Microcystis aeruginosa bloom using dual isotope tracer. Mar. Drugs 15, 226-240. https://doi.org/10.3390/md15070226.

Kokocinski, M., Cameán, A.M., Carmeli, S., Guzmán-Guillén, R., Jos, A., Mankiewicz- Boczek, J., Metcalf, J.S., Moreno, I., Prieto, A.I., Sukenik, A., 2017. Chapter 12: Cylindrospermopsin and congeners. In: Meriluoto, J., Spoof, L., Codd, G.A. (Eds.), Handbook of Cyanobacterial Monitoring and Cyanotoxin Analysis, $1^{\text {st }}$ ed. Wiley, NJ, USA, pp. 127-137.

Li, Y.W., Zhan, X.J., Xiang, L., Deng, Z.S., Huang, B.H., Wen, H.F., Sun, T.F., Cai, Q.Y., Li, H. Mo, C.H., 2014. Analysis of trace microcystins in vegetables using solid-phase extraction followed by high performance liquid chromatography triple-quadrupole mass spectrometry detection. J. Agric. Food Chem. 62, 11831-11839. https://doi.org/10.1021/jf5033075.

Lim, J.W., Shin, S.M., Jung, S.J., Lee, M.k., Kang, S.Y., 2019. Optimization of antibacterial extract from lacquer tree (Rhus verniciflua Stokes) using response surface methodology and its efficacy in controlling edwardsiellosis of olive flounder (Paralichthys olivaceus). Aquaculture 502, 40-47. https://doi.org/10.1016/j.aquaculture.2018.12.008. 
Llana-Ruiz-Cabello, M., Jos, Á., Cameán, A.M., Oliveira, F., Barreiro, A., Machado, J., Azevedo, J., Pinto, E., Almeida, A., Campos, A., Vasconcelos, V., Freitas, M., 2019. Analysis of the Use of Cylindrospermopsin and/or Microcystin-Contaminated Water in the Growth, Mineral Content, and Contamination of Spinacia oleracea and Lactuca sativa. Toxins 11, 624-644. https://doi.org/10.3390/toxins11110624.

Machado, J., Campos, A., Vasconcelos, V., Freitas, M., 2017. Effects of microcystin-LR and cylindrospermopsin on plant-soil systems: A review of their relevance for agricultural plant quality and public health. Environ. Res. 153, 191-204. https://doi.org/10.1016/j.envres.2016.09.015.

Magnusson, B., Örnemark, U., (eds.) Eurachem Guide: The fitness for purpose of analytical methods - A laboratory guide to method validation and related topics, (2 ${ }^{\text {nd }}$ ed. 2014). ISBN 97891-87461-59-0. Available from www.eurachem.org.

Manubolu, M., Lee, J., Riedl, K.M., Kua, Z.X., Collart, L.P., Collart, S.P., Ludsin, S.A., 2018. Optimization of extraction methods for quantification of microcystin-LR and microcystin-RR in fish, vegetables, and soil matrices using UPLC-MS/MS. Harmul Algae 2018, 76, 47-57. https://doi.org/10.1016/j.hal.2018.04.009.

Mekebri, A., Blondina, G.J., Crane, D.B., 2009. Method validation of microcystins in water and tissue by enhanced liquid chromatography tandem mass spectrometry. J. Chromatogr. A 1216, 3147-3155. https://doi.org/10.1016/j.chroma.2009.01.095.

Miller, M. A., Kudela, R.M., Mekebri, A., Crane, D., Oates, S.C., Tinker, M.T., Staedler, M., Miller, W.A., Toy-Choutka, S., Dominik, C., Hardin, D., Langlois, G., Murray, M., Ward, K., Jessup, D.A., 2010. Evidence for a novel marine harmful algal bloom: Cyanotoxin (microcystin) transfer from land to sea otters. PLOS One 5, 1-11. https://doi.org/10.1371/journal.pone.0012576. 
Miller, N.J., Miller, J.C. (Eds.), 2000. Statistics and Chemometrics for Analytical Chemistry. Fourth Edition. Pearson Education Limited. ISBN: 0-13-022888-5.

Moreno, I.M., Molina, R., Jos, Á., Picó, Y., Cameán, A.M., 2005. Determination of microcystins in fish by solvent extraction and liquid chromatography. J. Chromatogr. A 1080, 199-203. https://doi.org/10.1016/j.chroma.2005.05.029.

Norris, R.L.G., Seawright, A.A., Shaw, G.R., Senogles, P., Eaglesham, G.K., Smith, M.J., Chiswell, R.K., Moore, M.R., 2002. Hepatic xenobiotic metabolism of cylindrospermopsin in vivo in the mouse. Toxicon 40, 471-476. https://doi.org/10.1016/S0041-0101(01)00243-4.

Oehrle, S.A., Southwell, B., Westrick, J., 2010. Detection of various freshwater cyanobacterial toxins using ultra-performance liquid chromatography tandem mass spectrometry. Toxicon 55, 965-972. https://doi.org/10.1016/j.toxicon.2009.10.001.

Oliveira, G. D. A., De Oliveira, A. E., Da Conceição, E. C., Leles, M. I., 2016. Multiresponse optimization of an extraction procedure of carnosol and rosmarinic and carnosic acids from rosemary. Food Chem. 211, 465-473. doi:10.1016/j.foodchem.2016.05.042.

Ohtani, I., Moore, R.E., Runnegar, M.T.C., 1992. Cylindrospermopsin, a potent hepatotoxin from the blue-green alga Cylindrospermopsis raciborskii. J. Am. Chem. Soc. 114, 7941-7942. https://doi.org/10.1021/ja00046a067.

Otto, M., (Ed.). 2016. Chemometrics: statistics and computer application in analytical chemistry. In: John Wiley \& Sons. ( $3^{\text {rd }}$ ed). ISBN: 978-3-527-34097-2

Pal, C. B. T., Jadeja, G. C., 2019. Microwave-assisted deep eutectic solvent extraction of phenolic antioxidants from onion (Allium cepa L.) peel: a Box-Behnken design approach for optimization. J.Food Sci. Technol. 56, 4211-4223. https://doi.org/10.1007/s13197-019-03891-7. 
Papadimitriou, T., Kagalou, I., Stalikas, C., Pilidis, G., Leonardos, I.D., 2012. Assessment of microcystin distribution and biomagnification in tissues of aquatic food web compartments from a shallow lake and evaluation of potential risks to public health. Ecotoxicology 21, 1155-1166. http://doi.org/10.1007/s10646-012-0870-y.

Peacock, M. B., Gibble, C. M., Senn, D. B., Cloern, J. E., Kudela, R. M., 2018. Blurred lines: Multiple freshwater and marine algal toxins at the land-sea interface of San Francisco Bay, California. Harmful Algae 73, 138-147. https://doi.org/10.1016/j.hal.2018.02.005.

Pekar, H., Westerberg, E., Bruno, O., Lääne, A., Persson, K.M., Sundström, L.F., Thim, A.M., 2016. Fast, rugged and sensitive ultra high pressure liquid chromatography tandem mass spectrometry method for analysis of cyanotoxins in raw water and drinking water- First findings of anatoxins, cylindrospermopsins and microcystin variants in Swedish source waters and infiltration ponds. J. Chromatogr. A $\quad$ A 1429, 265-276. https://doi.org/10.1016/j.chroma.2015.12.049.

Preece, E.P., Moore, B.C., Hardy, F.J., Deobald, L.A., 2015a. First detection of microcystin in Puget Sound, Washington, mussels (Mytilus trossulus), Lake Reserv. Manage. 31, 50-54. https://doi.org/10.1080/10402381.2014.998398.

Preece, E.P., Moore, B.C., Hardy, F.J., 2015b. Transfer of microcystin from freshwater lakes to Puget Sound, WA and toxin accumulation in marine mussels (Mytilus trossulus). Ecotoxicol. Environ. Saf. 122, 98-105. http://dx.doi.org/10.1016/j.ecoenv.2015.07.013.

Prieto, A.I., Guzmán-Guillén, R., Valderrama-Fernández, R., Jos, A., Cameán, A.M., 2017. Influence of Cooking (Microwaving and Broiling) on Cylindrospermopsin Concentration in Muscle of Nile Tilapia (Oreochromis niloticus) and Characterization of Decomposition Products. Toxins 9, 177-189. https://doi.org/10.3390/toxins9060177.

Puerto, M., Campos, A., Prieto, A.I., Cameán, A.M., Martinho de Almeida, A., Coelho, A.V., Vasconcelos, V., 2011. Differential protein expression in two bivalve species; Mytilus 
Galloprovinciales and Corbicula Fluminea; exposed to Cylindrospermopsis Raciborskii Cells. Aquat. Toxicol. 101, 109-116. https://doi.org/10.1016/j.aquatox.2010.09.009.

Ríos, V., Moreno, I., Prieto, A.I., Puerto, M., Gutiérrez-Praena, D., Soria-Díaz, M.E., Cameán, A.M., 2013. Analysis of MC-LR and MC-RR in tissue from freshwater fish (Tinca tinca) and crayfish (Procambarus clarkii) in tench ponds (Cáceres, Spain) by liquid chromatography-mass spectrometry (LC-MS). Food Chem. Toxicol. 57, 170-178. Doi: http://dx.doi.org/10.1016/j.fct.2013.03.025.

Rodsamran, P., Sothornvit, R., 2019. Extraction of phenolic compounds from lime peel waste using ultrasonic-assisted and microwave-assisted extractions. Food Biosci. 28, 66-73. https://doi.org/10.1016/j.fbio.2019.01.017.

Ruiz, M.J., Cameán, A.M., Moreno, I.M., Picó, Y., 2005. Determination of microcystins in biological samples by matrix solid-phase dispersion and liquid chromatography-mass spectrometry. J. Chromatogr. A 1073, 257-262. https://doi.org/10.1016/j.chroma.2004.08.128.

Runnegar, M.T., Kong, S.M., Zhong, Y.Z., Lu, S.C., 1995. Inhibition of reduced glutathione synthesis by cyanobacterial alkaloid cylindrospermopsin in cultured rat hepatocytes. Biochem. Pharmacol. 49, 219-225. https://doi.org/10.1016/S0006-2952(94)00466-8.

Saker, M.L., Metcalf, J.S., Codd, G.A., Vasconcelos, V.M., 2004. Accumulation and depuration of the cyanobacterial toxin cylindrospermopsin in the freshwater mussel Anodonta cygnea. Toxicon 43, 185-194. https://doi.org/10.1016/j.toxicon.2003.11.022.

Sanseverino, I., Conduto, D., Loos, R., Lettieri, T., 2017. Cyanotoxins: methods and approaches for their analysis and detection. JRC Technical Reports. EUR-28624. https://doi.org/10.2760/36186.

Sivonen, K., Jones, G., 1999. Cyanobacterial toxins. In: Chorus, I., Bartram, J. (Eds.), Toxic Cyanobacteria in Water: A Guide to Their Public Health Consequences, Monitoring, and 
Management. E and FN Spon, London/New York, 41-11. http://apps.who.int/iris/bitstream/10665/42827/1/0419239308_eng.pdf.

Smith, J.L., Boyer, G.L., 2009. Standardization of microcystin extraction from fish tissues: a novel internal standard as a surrogate for polar and non-polar variants. Toxicon 53, 238-245. https://doi.org/10.1016/j.toxicon.2008.11.007.

Spoof, L., Catherine, A., 2017. Appendix 3. Tables of microcystins and nodularins. In: Meriluoto, J., Spoof, L., Codd, J. (Eds.), Handbook of cyanobacterial monitoring and cyanotoxin analysis. Wiley, Hoboken, 526-538. https://doi.org/10.1002/9781119068761.

Štraser, A., Filipič, M., Žegura, B., 2011. Genotoxic effects of the cyanobacterial hepatotoxin cylindrospermopsin in the HepG2 cell line. Arch. Toxicol. 85, 1617-1626. https://doi.org/10.1007/s00204-011-0716-z.

Tatters, A. O., Meredith, D.A.H., Nagoda, C., Busse, L., Gellene, A.G., Caron, D.A., 2017. Multiple stressors at the land-sea interface: Cyanotoxins at the land-sea interface in the Southern California Bight. Toxins 9, 95-111. doi:10.3390/toxins9030095.

Terao, K., Ohmori, S., Igarashi, K., Ohtani, I., Watanabe, M.F., Harada, K.I., Ito, E., Watanabe, M., 1994. Electron microscopic studies on experimental poisoning in mice induced by cylindrospermopsin isolated from blue-green alga Umezakia natans. Toxicon 32, 833-843. https://doi.org/10.1016/0041-0101(94)90008-6.

Testai, E., Buratti, F.M., Funari, E., Manganelli, M., Vichi, S., Arnich, N., Biré, R., Fessard, V., Sialehaamoa, A., 2016. Review and analysis of occurrence, exposure and toxicity of cyanobacteria toxins in food. EFSA supporting publication EN-998. 1-309. https://doi.org/10.2903/sp.efsa.2016.EN-998.

Turner, A.D., Waack, J., Lewis, A., Edwards, C., Lawton, L., 2018. Development and singlelaboratory validation of a UHPLC-MS/MS method for quantitation of microcystins and 
nodularin in natural water, cyanobacteria, shellfish and algal supplement tablet powders. J. Chromatogr. B 1074-1075, 111-123. https://doi.org/10.1016/j.jchromb.2017.12.032.

Vareli, K., Zarali, E., Zacharioudakis, G.S.A., Vagenas, G., Varelis, V., Pilidis, G., Briasoulis, E., Sainis, I., 2012. Microcystin producing cyanobacterial communities in Amvrakikos Gulf (Mediterranean Sea, NW Greece) and toxin accumulation in mussels (Mytilus galloprovincialis). Harmful Algae 15, 109-118. https://doi.org/10.1016/j.hal.2011.12.005.

Vasconcelos, V.M., 1995. Uptake and depuration of the heptapeptide toxin microcystin-LR in Mytilus galloprovincialis. Aquat. Toxicol. 32, 227-237. https://doi.org/10.1016/0166445X(94)00085-5.

Y1lmaz, F. M., Karaaslan, M., Vardin, H., 2015. Optimization of extraction parameters on the isolation of phenolic compounds from sour cherry (Prunus cerasus L.) pomace. J. Food Sci. Technol. 52(5), 2851-2859. doi:10.1007/s13197-014-1345-3.

WHO (World Health Organization), 2003. $2^{\text {nd }}$ Ed. Addendum to Vol. 2. Health criteria and other supporting information. Cyanobacterial toxins: Microcystin-LR in Drinking water. Background document for development of WHO. Guidelines for Drinking-water Quality World Health Organization, $\quad$ Geneva, 1-18. Geneva, 1998. http://www.who.int/water_sanitation_health/dwq/chemicals/cyanobactoxins.pdf?ua=1 (accessed on 10 February 2020).

Zervou, S.K., Christophoridis, C., Kaloudis, T., Triantis, T.M., Hiskia, A., 2017. New SPE-LCMS/MS method for simultaneous determination of multi-class cyanobacterial and algal toxins. J. Hazard. Mater. 323, 56-66. https://doi.org/10.1016/j.jhazmat.2016.07.020. 